\title{
Feasting and Forgetting: Sir Toby and the Lure of Lethe
}

Tobias Döring

\section{(2) OpenEdition}

Journals

\section{Electronic version}

URL: http://journals.openedition.org/shakespeare/1708

DOI: 10.4000/shakespeare. 1708

ISSN: 2271-6424

\section{Publisher}

Société Française Shakespeare

\section{Printed version}

Date of publication: 3 March 2012

Number of pages: $67-80$

ISBN: 2-9521475-8-2

\section{Electronic reference}

Tobias Döring, «Feasting and Forgetting: Sir Toby and the Lure of Lethe », Actes des congrès de la Société française Shakespeare [Online], 29 | 2012, Online since 03 March 2012, connection on 04 May 2019. URL : http://journals.openedition.org/shakespeare/1708 ; DOI : 10.4000/shakespeare.1708

This text was automatically generated on 4 May 2019.

(c) SFS 


\title{
Feasting and Forgetting: Sir Toby and the Lure of Lethe
}

\author{
Tobias Döring
}

1 "If music be the food of love, play on / Give me excess of it, that surfeiting / The appetite may sicken and so die." (I.i.1-3). ${ }^{1}$ Given Orsino's wonderful imperative, there can be no doubt whatsoever that Twelfth Night is a play about the arts of the table. Thoroughly obsessed with appetites, with eating, drinking, food consumption and excess, this festive comedy offers rich occasion through its staging, not only of great lovers, but specifically of food lovers such as Sir Toby Belch, the title part and the central interest of my paper. Yet even apart from showing us this potent figure, on which contemporary food debates converge, Twelfth Night is relevant for our topic because consumption figures prominently also in another way: the very language of the play is steeped in culinary and/or alimentary images, i.e. metaphors or similes that draw on the experience of eating. When, for example, Orsino criticizes what he sees as women's superficial love, he calls their love an "appetite / No motion of the liver but the palate, / That suffer surfeit, cloyment and revolt", whereas he calls his own love "hungry as the sea" that "can digest as much" (II .iv.97-101), thus naturalizing his misogyny by means of metabolic language and articulating his desire through a physiological figure. This is, of course, entirely appropriate for a comedy which announces its connection to the festive season already in its title and, in this way, seems to give license to contemporary spectators to indulge their own desires, with excessive eating, drinking, play going and feasting, quite possibly involving also sex.

2 What does it mean to speak of cooking as an art? More to the point, what would this have meant in the Renaissance? How would English audiences in the early seventeenth century have regarded gastronomic, gustatory or culinary feats in terms of artistic concepts? Could the table for them be a platform of performance which they experienced or conceived as art? No doubt, banqueting was a well established part of English Renaissance culture, especially aristocratic culture; it gave a social occasion as well as a performative matrix for the theatrical culture of the period. ${ }^{2}$ Yet, there are reasons to be cautious before applying later and emphatic notions of "the arts" to the historical practice we are 
looking at. Renaissance cooks were lowly figures, modest artisans who never rose to prominence and hardly even can be named. Despite the clear enjoyment of excessive culinary feasts, on the part of the elites, despite also increased sophistication, even in England, in preparing and in celebrating sumptuous banquets, Renaissance discourses seem to have placed little emphasis on their cultural, let alone artistic value.

This may derive from humanistic prejudices against cooking as a fraudulent, deceptive practice, an attitude most famously expressed in classical antiquity by Socrates. The locus classicus for the resistance to cookery is the Platonic dialogue Gorgias where cooking is condemned because its artifice tends to supplant the proper art of medicine. As Socrates explains:

Cooking assumes the form of medicine, and pretends to know what foods are best for the body; so that if a cook or a doctor had to contend before boys, or before men as foolish as boys, as to which of the two, the doctor or the cook, understands the question of sound and noxious foods, the doctor would starve to death. Flattery, however, is what I call it, and I say that this sort of thing is a disgrace. ${ }^{3}$

4 As Michel Jeanneret writes in his excellent study Des mets et des mots, ${ }^{4}$ cooking is condemned for two reasons, morally and epistemologically: first because "it only seeks to please" and secondly because "it cannot explain the true nature of things or establish causality". On both accounts, cookery operates like rhetoric, hence must be treated with suspicion and be banned from the ideal state. In just this way, the cook's art was rarely given credit in early modern times, let alone regarded as an art: too closely connected to physical functions and to the lower bodily spheres to be seen as contributing to any more refined activities, the kitchen hardly ranked among the places to which other cultural producers might seek affiliation or from which they might gain cultural prestige.

5 What, then, does this mean for our reading of Shakespearean drama and especially of plays which, like Twelfth Night, evidently gain much cultural significance from their connection to the kitchen sphere? What cultural work is being performed here? And what may be the actual function of food practices, food rituals and food references on the early modern English stage? These questions lead the way towards a better, and more satisfactory, understanding of the cultural relevance of food in early modern drama, a relevance which, I contend, involves the early modern politics of memory and forgetting. Quite a bit of work has recently been done on the question of food items featured on the Shakespearean stage and on contemporary attitudes towards them. ${ }^{5}$ Interesting as such publications clearly are, they need to be complemented by the functional questions I just raised. To list and classify dramatic food references, would then only be the first step in a larger exploration of how early modern theatre culture positioned itself towards early modern gastronomic culture, an exploration that may lead us also towards understanding what "the arts of the table" for Shakespearean audiences might have been.

For this purpose, my argument will offer two opposing views which both focus on the figure of Sir Toby but which place this figure in rather contrary perspectives. The traditional view sees Sir Toby - the famous drunkard, glutton, misbehaver and upsetter of the household order, great appreciator as well as instigator of excess - as a memorial character, i.e. a festive figure that embodies for Shakespearean audiences specific memories of their recent past. In contrast to this view, I would like to suggest that we should also see Sir Toby as a figure of forgetting and forgetfulness, a character by which specific cultural memories might be released. To make this point, I shall proceed in three steps. In a first step I will briefly review the evidence for well established accounts of Sir 
Toby and his gluttony as carnivalesque celebrations and commemorations of merry old England and its religion; in the second step I will reverse this perspective and offer my alternative view of this figure; and in the final part I'll try to draw a few (preliminary) conclusions from this discussion.

\section{1.}

7 The comedy comes to its first climax in the so-called "kitchen scene", act II, scene iii. Even though the setting here is never specified, this is traditionally seen as the appropriate location where the nightly drinking and carousing of Sir Toby and his friends takes place. Interestingly, in the entire Shakespeare canon we find thousands of references to food, eating and cooking, but we find no other single scene that is set in a kitchen (with the possible exception of the cauldron-scene in Macbeth, which might have been written by Middleton). ${ }^{6}$ This seems remarkable not least because, historically, the connections between theatre culture and gastronomic culture used to be quite close: courtly banquets and their entertainments, Richard Tarlton's pub in Gracechurch Street or John Heminges' tavern by the Globe all demonstrate the cultural interrelations between playhouse and alehouse, which are in fact part of the pre-history of the London theatres, as is explicitly recalled here: "Do ye make an alehouse of my lady's house" (II.iii.87-88), this is how Malvolio rebukes the nightly drinkers.

Yet even before his entry, the space of the stage has been turned into the gastronomic space of an inn, when Feste greets Sir Andrew and Sir Toby with the words: "Did you never see the picture of 'we three'?" (II.iii.15-16). The picture he refers to is a well-known pub sign: it shows two asses or two fools with the caption "We three loggerheads". And whoever wonders where the third ass or fool might be, has already solved the riddle, because the picture counts in the beholder. In the words of Elizabeth Freund, "without conceding asshood, the reader cannot unriddle the picture; but if he fails to read the picture, he is palpably an ass". ${ }^{7}$ That is to say, in more positive terms, that this picture, like this kitchen scene, fulfils a social function: they both construct communities. As much as the interpreter of the pub sign sees himself included in what he interprets, so spectators of this comedy find themselves included into the community of drinkers they are watching. As they follow the performance of the kitchen scene, quite possibly themselves eating and drinking, they become participants and potentially enter the theatrical space. Under Sir Toby's prompting, spectators turn into fellow-feasters.

It is only with this metatheatrical twist, turning the playhouse into an alehouse and thus returning to the prehistory of the London stage, that we can understand Malvolio's opposition to the spectacle. When Maria calls him "a kind of Puritan" (II.iii.136), we need not even take this in the strict religious sense to realize that Malvolio represents a new regime of social, temporal and spatial economies, quite the opposite to Sir Toby's theatrical transgressions. Malvolio demands respect for "place, persons" and "time" (II .iii.90), whereas Toby constantly violates these categories (and later makes Malvolio violate them, too: this is the particular cruelty of their hoax), just as the practice of the theatre must violate them, i.e. constantly transform place, person and time, in order to do its work. Sir Toby thus emerges as an emblematic figure of the theatre, an embodiment not just of bodily enjoyment but of theatrical practice which allies itself to the work of feasting. He upsets the household order, heeds neither place nor time, 
reverses social hierarchies and turns spectators into participants, thus constructing a community realized in performance.

This is the reason why his famous retort to Malvolio carries so much cultural force: "Dost thou think because thou art virtuous there shall be no more cakes and ale?" (II.iii.112-13), and this is why the conflict between Sir Toby and Malvolio has long given the cue to the Bakhtinian readings of the play, which I am summarizing here. According to Bakhtin's well-known analysis, "eating, drinking, defecation [...] as well as copulation" combine to construct what he calls the "grotesque body", the all-devouring, swelling and excessive physicality, which goes beyond all boundaries and which is realized through carnival. From its first lines, Twelfth Night surely is a comedy so steeped in food and carnival that the play's central confrontation between Sir Toby and Malvolio fits into the traditional patterns of "The battle between carnival and lent", which Peter Brueghel painted in his magnificent 1559 canvas, patterns which are here revived in the two figures and the seasonal celebration commemorated with their play.

This is historically significant because the comedy could thus be seen for the specific memory traces of the popular carnival culture which it involves and evokes, as if to offer an occasion for late-Elizabethans to relive an abandoned aspect of their Catholic past. For under Anglican auspices around 1600, the old calendar of seasonal festivities was clearly under pressure to reform. Shakespearean theatre therefore, it has been argued, may serve a crucial cultural function in reminding audiences of such rites and seasons officially no longer tolerated nor observed. Yet below the level of theological teaching and state church practice, many of the old notions lived on, especially the festive calendar which, according to the classic study by François Laroque, "still played a role of major importance in Elizabethan England" and constituted, as he puts it, "a veritable matrix of time". In the context of Twelfth Night, a threshold play performed just before the beginning of a new dynastic era long anticipated also with religious hopes, this "matrix of time" seems to be recalled with the presence of Sir Toby. He clearly operates as a memory figure, a Lord of Misrule, pitted against contemporary adversaries like the "Puritan" Malvolio. Food, generally speaking, often has or serves memorial functions, especially in religious rites. But even more so on stage, where Sir Toby appears as the central agent of traditional carnival culture: his food preferences may restore a sense of cultural continuity for what has otherwise been discontinued in English religious life.

This is, at any rate, suggested by the specific food items he mentions in his retort to Malvolio. For English audiences around 1600, "cakes and ale" hold particular resonances which are, in fact, references to the old faith. According to Ken Albala, ${ }^{10}$ there is a confessional divide involved, for instance, in the difference between real ale, the traditional English drink which Sir Toby is defending here, and beer, a new-fangled drink brewed with hops and, on the level of popular opinion, not really part of the traditional way of things in England, just like the Reformation. ${ }^{11}$ This connection between gastronomic and religious culture was not lost on stout defenders of the faith, judging from popular verses such as "Hops, Reformation, Bays and Beer / Came all into England in one bad year"12 or "heresie \& beer came hopping into England both in a yeere." ${ }^{13}$ These are just small indications of the many ways in which the new religion followed or produced also a new dietary regime. Another highly interesting example would be fish, strongly associated with Catholic practice, hence outlawed under Protestantism and only tolerated by Elizabethans, in a typically pragmatic compromise, so as to protect the local fishing industry. It is relevant to note, therefore, that fish consumption, too, is 
characteristic for Sir Toby, above all "pickle herring", evident in his frequent hiccups (I .v.117) and giving evidence of his traditional standing.

All these examples, then, should serve to make two points about Sir Toby: they show him as a figure of excess and as representing special diets. Excess links him to the old carnival tradition, and the dietary preferences to the old faith. In both these ways Sir Toby's presence on the stage may indeed help to revive a sense of ritual practice and to recall for all theatrical participants - which, as we have seen, potentially includes the audience the old matrix of time. Against the virtuous Malvolios and modern "time-pleasers" (II .iii.143) in late-Elizabethan England, Sir Toby reconstitutes a different regiment of temporal organization, of seasonal celebration and festivity, provisionally re-established in the theatre as in a space of cultural memory. And yet, as I said earlier, this is just half his story. I believe we need to question this account and reverse the functional perspective on this figure to see what it also and primarily performs: the work of cultural forgetting - a function of the theatre, I would like to suggest, much in demand in postReformation England.

\section{2.}

When Sir Toby makes his first appearance on stage, he talks about his niece Olivia and rebukes her for continued care: "I am sure", he says, "care's an enemy to life" (I.iii.2). This is entirely in keeping with the way in which Orsino's messenger in the first scene described Olivia: like a nun, living withdrawn, constantly weeping and mourning for her brother. Even before the Countess makes an actual appearance, she has been billed and introduced as a persistent mourner. So it comes as no surprise, when we actually meet her first, that the legitimacy of mourning is the issue of her celebrated little dialogue with the fool, who keeps calling her "Madonna":

FESTE. Good madonna, why mourn'st thou?

Olivia. Good fool, for my brother's death.

Feste. I think his soul is in hell, madonna.

Olivia. I know his soul is in heaven, fool.

Feste. The more fool, madonna, to mourn for your brother's soul being in heaven.

(i.v.62-7)

15 The fool's argument is a clear echo of well-known Protestant polemics against Catholic funeral rites, manifest in many treatises such as Thomas Becon's The Sick Mans Salue ${ }^{14}$ of 1560 , immensely popular and frequently reprinted, which makes precisely the same point: "Let the Infidels mourne for their dead: the Christian ought to reioyce when any of the faythfull be called from this vale of misery vnto the kingdome of God." ${ }^{15}$ That is to say, Olivia's ostentatious mourning aligns her with the Catholic rites outlawed a generation earlier.

This diagnosis is confirmed by a crucial detail later, when the Countess goes to marry her new love and asks her bridegroom: "go with me and with this holy man / Into the chantry by" (IV.iii.23-4), i.e. into her chapel dedicated to the singing of daily mass for the souls of the dead, ${ }^{16}$ where now her wedding is to be performed. Even though governed by a timekeeping "Puritan" steward, her Illyrian household is evidently built on Catholic ground. So it is entirely appropriate that her fool utters Catholic curses ("By'r Lady", "by Saint Anne", II.iii) but otherwise speaks the language of the Reformation and, in his songs, of the new Protestant eschatology ("What's to come is still unsure", II.iii.48). In this 
perspective, then, we see how the theatrical performance offers an occasion to remember, once again, specific rites and doctrines of the old religion and how it is the figure of Olivia who functions to induce such cultural memories. If the early modern playhouse is a space for the art of memory, as Frances Yates argued long ago, ${ }^{17}$ this would include religious memories and may indeed give compensation for a specific ritual practice, such as mourning, discontinued in Elizabethan England. ${ }^{18}$

But is it? Would it really do so? I think there is scope for difference, and I think we need to reconsider the work of early modern theatre in dealing with memory and mourning. As indicated earlier, the theatre contributes in my view also to the work of cultural forgetting, and it is the figure of Sir Toby with his constant gluttony who can take the lead for such a project. To make this argument, I need to add a short digression, considering the concept I have been referring to, "cultural forgetting", a concept which may well seem paradoxical because it reverses the fundamental notion on which our understanding of memory is generally grounded. The art of memory, or ars memorativa, is, of course, a classic heritage from the rhetorical tradition: in the course of training orators, it offers them techniques to memorize a speech which they would otherwise, eventually and naturally, forget. In this tradition, memory is to forgetting as culture is to nature: ${ }^{19}$ a man-made intentional effort meant to compensate and combat processes beyond human volition.

18 Against this background, an art of oblivion would be quite impossible because forgetting could never be an art in the sense of an intentional, controlled and specific technique. Any act that tries to make someone forget something must, inevitably, call this very thing again to mind: a performative contradiction, which led thinkers like Umberto Eco to categorically deny it. "An Ars Oblivionalis?" Eco entitled a famous article in the 1980s, only to give his answer at once: "Forget it!" ${ }^{20}$ And yet, the term occurs in early modern literature, most prominently in a 1618 rhetoric textbook by John Willis, who defines the "Art of Oblivion" as a "Deposition or discharging [of] things committed to mind". ${ }^{21}$ Political uses of this art are discussed by Niccolò Machiavelli in the second book of his Discorsi, when he remarks about the introduction of a new religion that natural catastrophes like plagues or famines are so useful for this purpose because they help to erase memories of the old religion quite efficiently, making people forget and thus purging the body politic of unwanted remains and lingering recollections. ${ }^{22}$

Machiavelli's reference to Galenic physiology and the economy of body fluids here is crucial: it sets up the process of food consumption and digestion as a counter-force and counter-exercise to memory, especially when this consumption is taken to excess. As Willis tells us in his treatise: "Variety of dishes, diversity even of wholesome meats is evil, of Sauces worst of all, distracting the stomack by concocting food of several qualities." ${ }^{23}$ He therefore advises all diligent students of memory to moderation: "Fly therefore Drunkennesse and Gluttony, as the mortallest enemies of a good Memory." ${ }^{24}$ It is precisely on the basis of this logic that we may understand why, if anyone finds reason to promote forgetting as a cultural force, he can best do so by promoting eating, feasting, drunkenness and gluttony. Which brings us back to Toby and his cultural function. When he meets Olivia for the first time in the play - belching, reeking of herring, evidently drunk and in top spirits -, she rebukes him with the words: "Cousin, cousin, how have you come so early by this lethargy?" (I.v.119). Lethargy is the key-word here: it designates his lack of discipline, his gluttonous enjoyment beyond body norms, and his self-forgetting. Etymologically, the word lethargy derives from the river Lethe, the 
underworld river of forgetfulness, which links the pathology of excessive body fluids to a lack of memory. As Garrett Sullivan has argued on the basis of medical literature: "the operations of animal spirits in the brain are impeded by the preponderance of phlegm". ${ }^{25}$ The glutton and drunkard is lethargic because he is fully focused on his physicality, hence unable to perform any cultural work - except, we should add, the work of cultural forgetting.

For we need not see this work of cultural forgetting entirely in negative terms, as suggested by Olivia, who is, after all, a figure fixated on persistent memory. We should also see the bliss provided by the Lethean waters, the stream of forgetting, to anyone who would like to renew, perhaps even reform, himself or indeed reform society:

What relish is in this? How runs the stream?

Or I am mad or else this is a dream.

Let fancy still my sense in Lethe steep:

If it be thus to dream, still let me sleep. (Iv.i.59-62)

This is how Sebastian, Olivia's lover, describes the curious transformation that has overcome him, with reference to the lure of Lethe, as a blissful state, bathing in the waters of forgetting. Dreaming and sleeping are well-known traditional self-descriptions of the early modern theatre, which is thus linked to the workings of oblivion, while Sebastian's reference to "relish", i.e. to the physical pleasures of the palate, suggests that he has already joined the tribe of Toby.

Two points, then, emerge from this analysis: first, we realize that forgetting may involve productive and inventive powers which crucially enable reformations and the establishment of something new; secondly, we realize that the theatre may be a place where such powers are effective, i.e. where practices of eating, feasting and digesting perform continuous transformations of given elements and of persistent memories. If Sir Toby, as I argued, is a figure that embodies the theatrical and at the same time presents the theatrical as an art of the body, then his lethargy must have an impact also on spectators, who turn into participants and, as suggested with Sebastian, themselves partake of all these lures of Lethe. In such a revised perspective, Sir Toby's cultural work is as an agent of forgetting. Where does this leave us with our reading of the play, and for the larger issue about the "arts of the table"?

\section{3.}

According to Richard Wilson's reading of Twelfth Night, "Shakespeare's Illyria maps the religious politics of Elizabethan London." ${ }^{26}$ Indeed, as we have seen even from the few points cited, the text offers rich allusions to confessional divides, and especially rich reminders of the Catholic religion long suppressed. Not least the names of many characters - Maria, Sebastian, Fabian, Andrew, Valentine - echo names of the traditional saints, ${ }^{27}$ several of whom could no longer be commemorated by late-Elizabethan worshippers, except by proxy of the stage: as suggested, the Saints' theatrical return might well have helped to offer compensation for a seasonal practice now officially reformed and suppressed.

And yet, I would like to suggest that Shakespearean audiences may find even more occasion to experience the playhouse as a space of cultural forgetting, a space in which the names of Saints, for instance, are absorbed, erased or emptied out of former holiness. In my view, then, the main point about the various traces of the old religion in this 
comedy - traces evident also in the food obsession that is staged - may be neither to recall nor to resist Catholicism, but more simply to perform, transform, digest and outperform it on the stage, so as to be able to consign it to oblivion. Crucial for this function of the theatre is the figure of Sir Toby. Yet, the play offers two rather different views of him, so that he works as a twinned or double figure, like a "natural perspective" which Orsino mentions at the end (v.i.213). When we juxtapose Sir Toby to Malvolio, he appears to be a memory-figure, recalling the traditional rites of festive cycles which are increasingly suppressed in Protestant society, mainly to survive on the festive stage. But when we juxtapose him to Olivia, Sir Toby appears instead to be a figure of purgation, transformation and forgetting, that is to say, of getting rid of all such ritual memories in and by theatrical enactment. If Olivia, the persistent mourner, works as a figure of Catholic commemoration, Sir Toby functions not just to criticize her old beliefs but to help people forget them. For this is what feasting does: eating and drinking result in lethargy and thereby produce forgetting, letting people steep in river Lethe.

This is what I take to be the cultural work of theatre, an early modern institution, after all, which was routinely criticized by virtuous believers such as Philip Stubbes or William Rankins for inducing oblivion, "drinking the wine of forgetfulness", as Rankins put it in 1587 in A Mirrour of Monsters, ${ }^{28}$ and which was in this way functionally associated with the "arts of the table": precisely because of all the dangerous, incalculable physical forces which it involves. In the view of such perceptive critics of the stage we realize how feasting is allied to forgetting and both are allied to the playhouse where these obnoxious "arts" find their appropriate place - just as the "arts" of the table, which may culturally not be valorized and yet be quite effective. So when people enter such a space of pleasure and consumption, they may well encounter Catholic rites and figures there, but these, I contend, are recalled only in order to be consigned to oblivion: they figure as one part among many in some popular entertainment, among stage attractions and distractions, and even if they were once sacred, their theatrical return helps empty them of such significance. They reappear, to use the appropriate metaphor, just like a hiccup, a physical release.

Which is Sir Toby's cultural function, hence his surname Belch. ${ }^{29}$ Belching is just such a form of discharge, purifying us from unaccommodating elements which have been troubling or disturbing our system, so that we may feel more at ease.

And duller shouldst thou be than the fat weed

That roots itself in ease at Lethe wharf (Hamlet, I.v.32-3)

What Hamlet's ghost, another figure of persistent memory, thus evokes as a horrible monstrosity, returns a season later on the London stage with Sir Toby Belch, but with the valuation turned around: for this grotesque glutton, this "fat weed" is evidently quite at ease and he indeed invites us all to feel at ease, just like Sebastian, to steep our sense in Lethe and to relish our reformation. Twelfth Night therefore appears to offer us a twin drama to Hamlet, reworking the same issues of mourning, memory and melancholia, but in another key. Its functional connection of feasting and forgetting, in conclusion, may suggest that the early modern playhouse, too, was built in ease at Lethe wharf. 


\section{NOTES}

1. William Shakespeare, Twelfth Night, The Arden Shakespeare, third series, ed. Keir Elam, London, Arden Shakespeare, 2008. Subsequent parenthetical references will refer to this edition.

2. Chris Meads, Banquets Set Forth: Banqueting in English Renaissance Drama, Manchester, Manchester University Press, 2001.

3. Plato, Gorgias, trans. W. R. M. Lamb, London, Cambridge MA, Loeb Classical Library, 1967, p. 464.

4. Michel Jeanneret, A Feast of Words: Banquets and Table Talk in the Renaissance, trans. Jeremy Whiteley and Emma Huges, Chicago, University of Chicago Press, 1991, p. 81.

5. Joan Fitzpatrick, Food in Shakespeare: Early Modern Dietaries and the Plays, Aldershot, Ashgate, 2007; Joan Fitzpatrick, "Apricots, Butter and Capons: An Early Modern Lexicon of Food", S hakespeare-Jahrbuch 145 (2009), p. 74-90; Joan Fitzpatrick, “'I must eat my dinner': Shakespeare's Foods from Apples to Walrus", in Renaissance Food from Rabelais to Shakespeare: Culinary Readings and Culinary Histories, ed. Joan Fitzpatrick, Farnham, Ashgate, 2010, p. 127-144.

6. See Thomas Middleton, The Collected Works, eds. Gary Taylor and John Lavagnino, Oxford, Oxford University Press, 2007, p. 1165-1169.

7. Elizabeth Freund, "Twelfth Night and the tyranny of interpretation", English Literary History 53 (1986), p. 471-89, here p. 476.

8. M. M. Bakhtin, Rabelais and His World, trans. Helene Iswolsky, Bloomington, Indiana University Press, 1984, p. 316.

9. François Laroque, Shakespeare's Festive World: Elizabethan Seasonal Entertainment and the Professional Stage, trans. Janet Lloyd, Cambridge, Cambridge University Press, 1991, p. 81.

10. Ken Albala, Eating Right in the Renaissance, Berkeley, University of California Press, 2002.

11. I would like to thank Gilly Lehmann for many helpful clarifications on this point: in actual fact, beer was already brewed in England long before the Reformation, yet it seems as if cultural perceptions nevertheless associated it with the new religious trends.

12. Quoted in Albala, Eating Right, p. 230.

13. Ibid.

14. Thomas Becon, The Sicke Mans Salue, London, John Daye, 1582 [1560].

15. Ibid., p. 114.

16. Twelfth Night, op. cit., p. 319.

17. Frances Yates, The Art of Memory, London, Routledge \& Kegan Paul, 1966.

18. Tobias Döring, Performances of Mourning in Shakespearean Theatre and Early Modern Culture, London, New York, Palgrave, 2006.

19. Sibylle Krämer, "Das Vergessen nicht vergessen! Oder: ist das Vergessen ein defizienter Modus von Erinnerung?", Paragrana 9: 2, p. 251-75.

20. Umberto Eco, “An Ars Oblivionalis? Forget it!” PMLA 103 (1988), p. 254-261.

21. John Willis, Mnemonica, or The Art of Memory, London, 1661 [1618], p. 30.

22. Niccolo Machiavelli, Discorsi: Gedanken über Politik und Staatsführung, übers. Rudolf Zorn, Stuttgart, Kröner, 1977, p. 183.

23. Willis, Mnemonica, op. cit., p. 139.

24. Ibid., p. 140.

25. Garret A. Sullivan Jr., Memory and Forgetting in English Renaissance Drama: Shakespeare, Marlowe, Webster, Oxford, Oxford University Press, 2005, p. 30. 
26. Richard Wilson, Secret Shakespeare: Studies in Theatre, Religion and Resistance, Manchester, Manchester University Press, 2004, p. 279.

27. Twelfth Night, op. cit., p. 23.

28. Quoted in Sullivan, Memory and Forgetting, p. 20; see also Isabel Karremann, “Drinking the wyne of forgetfulnesse': The Ambivalent Blessings of Oblivion and the Early Modern Stage", [online paper], Wissenschaftliches Seminar Online 6 (2008), available from: http:// www.shakespeare-gesellschaft.de/publikationen/seminar/ausgabe2008/karremann.html, accessed 04/08/2011.

29. Cf. Robert Appelbaum, Aguecheek's Beef, Belch's Hiccup, and Other Gastronomic Interjections. Literature, Culture, and Food among the Early Moderns, Chicago, University of Chicago Press, 2006.

\section{ABSTRACTS}

For most of its critical history, Twelfth Night has been considered in relation to the rites and customs of seasonal festivities which, as its title indicates, the comedy in many ways recalls. Yet through theatrical replaying of such festive elements, long criticised and actively suppressed in post-Reformation England, this play also divests them of the ritual significance they once embodied and makes them part of a commercial entertainment industry. This is especially pertinent for the persistent rites of mourning and remembering the dead, staged in the figure of Olivia, but upstaged through Sir Toby's constant feasting. With reference to John Willis's contemporary treatise on the arts of memory, my paper argues that the close connection between eating, drinking and digesting performed in this figure ultimately serves to constitute a mode of cultural discharge, i.e. of actively evacuating ancient monuments and redefining old religious memories for purposes of aesthetic pleasure. The arts of the table, indicated with Sir Toby's constant drunkenness and "lethargy", thus perform the crucial function of theatrical purgation for the politics of cultural forgetting.

La critique de Twelfth Night a largement abordé la relation de la pièce aux rites et coutumes des festivités saisonnières, mentionnées à de nombreuses occasions dans la pièce ainsi que dans son titre même. Cependant, la représentation théâtrale de tels événements festifs, longtemps critiquée et définitivement supprimée en Angleterre après la Réforme, se manifeste dans la pièce au travers de l'effacement rituel de telles festivités au profit d'une industrie du divertissement commercial. Ceci est particulièrement significatif dans le cas des rites persistants liés au deuil et au souvenir des êtres disparus, incarnés en la personne d'Olivia mais détournés par les incessants banquets de Sir Toby. S'appuyant sur le traité des arts de la mémoire de John Willis, mon étude vise à démontrer que la relation étroite liant la boisson, la nourriture et la digestion, telle qu'elle est présentée par ce dernier personnage, a pour but de constituer un mode de décharge culturelle, c'est-à-dire d'évacuation active des rites ancestraux afin de redéfinir d'anciens souvenirs religieux à travers la recherche d'un plaisir purement esthétique. Les arts de la table, incarnés dans l'ivresse et la « léthargie " permanentes de Sir Toby, participent ainsi à la fonction cruciale de purge dramatique et instaurent une amnésie culturelle. 
INDEX

Keywords: cooking, food, Twelfth Night, ritual, memory

Mots-clés: cuisine, nourriture, Nuit des rois, rituel, mémoire

\section{AUTHOR}

TOBIAS DÖRING

Ludwig-Maximilians-Universität, Munich 